\title{
INSTITUTIONALIZATION AND ORGANIZATIONAL FAILURE IN TERRITORIAL ADMINISTRATIVE UNITS IN ECATEPEC, MEXICO
}

\section{INSTITUCIONALIZAÇÃO E INSUCESSO ORGANIZACIONAL EM UNIDADES ADMINISTRATIVAS TERRITORIAIS EM ECATEPEC, MÉXICO}

\author{
Benjamin Méndez Bahena ${ }^{1}$ \\ Pablo Armando Cruz Hernández ${ }^{2}$
}

\begin{abstract}
Usually, the creation, operation, and termination of organizations in the public sector fails to include organizational or planning elements; it also fails to take into account the citizenry and its key actors. This process is usually led by habit instead of rational guidelines, assessment, and planning aimed at meeting goals and demands. This conduct compromises the organization itself, its institutionalization process, and its ability to deliver benefits to the citizenry, which can result in its termination.

The academic sector has paid scant attention to public organization termination. As a leading perspective, organizational theory can be of help in understanding this phenomenon by emphasizing the institutional approach and citizen participation; the present study used this combined approach to present and analyze the termination of Territorial Administrative Units in Ecatepec, State of Mexico in order to contribute with the theoretical and empirical understanding of this phenomenon (Flyvbjerg, 2006). Due to the nature of this study, a hemerographic research, as well as interviews with key actors of the municipal government, such as ex-managers of the units, members of the municipal council, and the personal secretary of the mayor, were made in order to obtain the needed data for the understanding of the phenomenon. Hence, although within the study a cartographic analysis made with statistical data is included, a qualitative perspective is predominant.

Among the main findings, this study case allows to establish a recommendation for the public sector when creating, operating and evaluating its public organizations. Whenever the sector wants to foment the institutionalization process of its organizations, as well as try avoiding their failure, it should consider taking into account the elaboration of a deep analysis of the organizational actors, the planning processes and the citizen participation, as the theory and the empirical analysis have shown.
\end{abstract}

Keywords: Organizational theory, Strategic planning, Citizen participation, institutionalization process, Public organization termination.

\section{Resumo}

Geralmente, a criação, operação e encerramento de organizações no setor público não incluem elementos organizacionais ou de planejamento; também não são levados em conta os cidadãos e seus principais atores. Esse processo geralmente é conduzido pelo hábito, em vez de

\footnotetext{
${ }^{1}$ Research Professor at the Center for Economic, Administrative, and Social Science (CIECAS) at the National Polytechnic Institute (IPN), México. e-mail: bmendezb@hotmail.com y bmendez@ipn.mx

2 PhD of Social Science candidate at UAM-Cuajimalpa, Mexico. Master of Economics and Municipal Management, IPN, México. email stolzcross@hotmail.com
} 
diretrizes racionais, avaliação e planejamento destinados a atender às metas e demandas. Essa conduta compromete a própria organização, seu processo de institucionalização e sua capacidade de proporcionar benefícios aos cidadãos, o que pode resultar em sua rescisão.

O setor acadêmico prestou pouca atenção ao término da organização pública. Como perspectiva principal, a teoria organizacional pode ajudar na compreensão desse fenômeno enfatizando a abordagem institucional e a participação do cidadão; O presente estudo utilizou essa abordagem combinada para apresentar e analisar a extinção de Unidades Administrativas Territoriais em Ecatepec, Estado do México, a fim de contribuir com a compreensão teórica e empírica desse fenômeno (Flyvbjerg, 2006). Devido à natureza deste estudo, uma pesquisa hemerográfica, bem como entrevistas com atores-chave do governo municipal, como exgerentes das unidades, membros do conselho municipal e o secretário pessoal do prefeito, foram feitas em a fim de obter os dados necessários para a compreensão do fenômeno. Assim, embora dentro do estudo seja incluída uma análise cartográfica feita com dados estatísticos, predomina uma perspectiva qualitativa.

Entre as principais conclusões, este estudo permite estabelecer uma recomendação para o setor público ao criar, operar e avaliar suas organizações públicas. Sempre que o setor quer fomentar o processo de institucionalização de suas organizações, bem como tentar evitar seu fracasso, deve levar em consideração a elaboração de uma análise profunda dos atores organizacionais, dos processos de planejamento e da participação cidadã, como a teoria e os processos. a análise empírica mostrou.

Palavras-chave: Teoria organizacional, Planejamento estratégico, Participação cidadã, Processo de institucionalização, Encerramento de organizações públicas.

\section{INTRODUCTION}

Organizations are human constructs where members of society spend most of their time. Within them, individuals are trained and indoctrinated, and they surrender part of their decision-making autonomy so that organizational processes can take place. The study of organizations has traditionally focused on the private sector, but political science and sociology have approached these studies from public management and psychology. Moreover, most empirical studies based on organizational theory have centered on case studies from the US and occasionally from other western democratic systems (Christensen, Laegreid, Roness, \& Rovik, 2007).

Organizations can be analyzed using different perspectives; however, in organizational theory (OT), the institutional approach can be used as a way to understand the factors involved in organizational institutionalization processes, which makes their survival possible when facing unfavorable contexts, for instance political/administrative changes. This perspective can be complemented with elements of strategic planning and citizen participation (CP) theories inasmuch as the public sector, the content of public policies, and associated decision-making 
process can be better understood by OT by analyzing the way in which political administrative systems are organized and operate (Christensen et al., 2007).

Strategic planning (SP) helps to understand, firstly, the way in which organizations can be designed; secondly, the way in which objectives are created, and thirdly, the territorial and contextual characteristics to be considered when designing organizations and creating objectives, i.e., possible strengths and weaknesses associated with specific contexts. SP can also help in devising an organizational strategy aimed at securing the existence and survival of the organization (Arellano, et al, 2012; Perlman \& Rivera, 2006; Arellano, 2004; Mendoza, 2011; Porter, 1980; Armijo, 2009; Arellano, Cabrero \& Castillo, 2000; Surdez, 2011; Arce, et al., 2012; and Sánchez, 2012).

For its part, CP provides an analysis of the role of the population in the survival of an organization and its institutionalization possibilities; citizen actions can help organizations to meet their objectives by protecting them from changes in the context, or reject them and impede their work if they are considered unfavorable. An important argument at this point is that a public organization can be closed due to pressure and decisions of political actors, not necessarily due its failure in achieving expected results.

In this regard, there are several organizations in the public sector created with the aim of improving administrative efficiency and efficacy, or with the goal of solving unexpected problems. However, there are cases in which a government administration decides to maim institutionalization processes or even end their existence.

In this sense, institutional failure (including government and non-governmental bodies) seems to encourage a confidence decline of critical proportions in social, political, and economic institutions, which makes it necessary to conduct research to explain such failures using a theoretical referent and study them empirically instead of merely assuming their existence. These failures are mainly due to design, maladjustment, obsolescence, or capture issues (Parkash y Potosky, 2016).

Despite the decline of public confidence in the public sector, strategic factors such as organizational, planning, and CP characteristics are disregarded by governments as important aspects for the design and creation of their public organizations, which increases their odds of failure and mortality.

Therefore, the present study addresses the disappearance of public sector organizations as a contribution to the theoretical and empirical understanding of this phenomenon. Given the importance of the municipality of Ecatepec (State of Mexico) in terms 
of its social fabric complexity, population density, and political importance both at the state and national levels, this study examined (using plenty of empirical information) the Territorial Administrative Units (TAUs) created in 2013 by the municipal government and terminated in 2016 as a result of a decision by the new municipal administration. Two questions arise from this process: How can the TAU creation and termination process be explained? How can theory explain the phenomenon?

Consequently, this investigation had a double objective: on the one hand, to analyze the main organizational factors involved in the decision to terminate the TAUs, and on the other, to develop a proposal centered on the organizational aspects that the public sector should take into account when designing their agencies in order to increase their survival in the face of adverse circumstances and to eventually acquire institutional characteristics.

The first part of this paper presents the different theories used in this study: OT, SP, and CP. Secondly, the creation, operation, and termination of units is discussed. The third part presents theoretical aspects identified in this case in an attempt to obtain a theoretical perspective about the failure and termination of public organizations. Conclusions and basic recommendations are offered in the last section.

\section{ORGANIZATIONAL THEORY}

Organizations are human constructs around which the members of society spend most of their lives. They also establish environments where people's attributes and habits are gradually modeled. Individuals are trained and indoctrinated to yield their decision autonomy to organizational decision-making processes (Simon, 1982). As social creations, organizations are built by relatively autonomous actors who generate a structure via collective and cooperative action. This structure can be the result of formal actions or an expression of the evolution of historical, custom, or belief processes aimed at meeting objectives and providing solutions to common problems using specific resources and capacities (Crozier, 1990).

Two basic types of institutions are the public and the private. Public organizations are responsible for performing tasks for society; they can be seen as "tools or instruments for achieving certain goals seen as important in society" (Christensen et al., 2007: 20). The creation, objectives, procedures, and mechanisms used by public and private organizations to achieve their goals have important differences (Simon, 1982). Organizations also differ from one another in terms of their interests, norms, regulations, laws, values, type of accountability, 
characteristics of bureaucratic elements, transparency, impartiality, equal treatment, predictability, forms, functionality, quality of services, efficiency and effectiveness, political adscription, among others (Christensen et al., 2007). Nevertheless, they share common factors such as bureaucracy, where the duty of obedience is ranked in a hierarchy of positions that involves a vertical subordination rule and a controlled right of complaint (Weber, 1998).

For Simon, (1982), actors are the most important aspects of an organizational analysis. This author identifies three types: high-hierarchy actors, whose decisions control employee's activities; employees, whose time and effort contribute to the achievement of organizational objectives in exchange of a retribution, and thirdly, the beneficiaries of the products or services that bring inputs into the organization and for whom the organization is, indirectly, a personal goal. As an analogy, decision makers in high hierarchical levels are equivalent to the members of an elective bureaucracy in charge for a certain term; employees can be compared with an administrative apparatus staff, who work under the leadership of the elective bureaucrats, and the beneficiaries are the citizens who receive the product or service and are involved with and affected by the conduct of the public organism. This is relevant because, in the public sector, part of the bureaucracy can be integrated to the entity via citizen votes instead of hierarchical or rational processes, which brings a special dynamic to the hierarchies of appointed and elected officials where the latter are not accountable to a higher-ranking official (Weber, 1998).

Nevertheless, organizational actors may not only seek economic benefit, but also other ends such as security, convenience, and prestige. It should be noted that, given that organizations are created, composed of, and directed by people, they are not purely rational, since in real behavior, as opposed to rational behavior, decision is initiated by stimuli that channel attention to concrete decisions and the response to such stimuli is partially thought out, but mostly motivated by habit. The habitual part is not, of course, neither forced nor utterly irrational, because it can represent a previously conditioned adjustment or adaptation of behavior toward its purposes (Simon, 1982).

In this regard, organizations in the public sector can be created only in response to a law or regulation (Arellano, et al., 2000), not necessarily following rational processes based on a wide range of available information, as well as several alternatives to accommodate the creation of the most appropriate body and to achieve maximized benefits. Consequently, from the moment they are born, organizations build their own dynamics, face their own contexts, and build their internal structure and culture (Arellano, et al., 2000), which leads to the emergence of a situation where organisms constantly contain and coexist with both formal 
institutions (written rules assigning activities and establishing hierarchies, procedures, and communication channels) and informal institution ${ }^{3}$ (tacit rules, predecessors of and complementary to formal rules); institutions are also embedded in the relationships between individuals in organizations, further affecting the organizational decision-making process (Simon, 1982: Christensen, et al., 2007).

Informal institutions are a fundamental part of the organization: it would probably be fair to assert that no formal organization could function effectively without being accompanied by a non-formal structure. Every new organization must go through an initial 'adaptation phase' before being able to run smoothly, and each member in the organization must establish informal relationships with their colleagues before becoming a significant part of the organization (Simon, 1982). Additionally, even though institutional norms can change overnight as a result of political or legal decisions, the informal constraints embedded in customs, traditions, and codes of behavior are much more resistant or impervious to deliberate policy (North, 1995).

That is to say, an organization has formal rules, which should not be underestimated (Arellano, et al., 2000), but its members establish equally or more important informal rules, which makes it necessary to identify the type of non-formal relationships and actions produced and established historically in any organization with the aim of revealing its operation and the effect of such operation in its everyday duties.

Decisions and the way in which individuals interact within organizations are important from an organizational perspective because the best path to an intense vision of the structure and functioning of an organization is to analyze how decisions and employee behavior are influenced by the organization (Simon, 1982). Therefore, knowledge about an organization's objectives is necessary to understand decision-making mechanisms-objectives are the main reason for an organization to exist, and they guide individual decisions and efforts (Simon, 1982).

Decisions made by members of an organization aimed at achieving objectives must be approached from an inclusive perspective that takes into account the community's value system even further than what is legally established (Simon, 1982); therefore, it is important for organizations to understand their specific context and adapt themselves accordingly in order to avoid obstacles and leverage the environment to support organizational objectives.

\footnotetext{
3 "Institution" is used in the sense of North (1995) as the rules of a game created by humans which can evolve or be affected by individuals.
} 
Another relevant aspect of organizational objectives is their non-static nature: changing contexts and ever-changing beneficiary goals result in responses associated with satisfaction (Simon, 1982). Objectives are usually created in a complex and "volatile environment that is characterized by impatient politicians, scrutinizing media, critical citizens, and scarce resources" (Boin \& Christensen, 2008: 271). It is also important to identify the ambiguity of objectives: even if an organization was created for a specific purpose, it can be under pressure from other organisms, government levels, or actors to state ambiguous objectives and act in pursuit of goals different to its natural goals, which in turn results in significant influence over attitudes, behaviors, structure, processes, and types of authority within the organization, and it also becomes the reason behind the lack of a sense of belonging among its members toward the organization, or renders it impossible to establish a clear performance assessment (Rainey \& Jung, 2015).

Another important organizational aspect responds to the question about the influence of an organization's personnel on its work. An important characteristic of organizations is that they are composed by internal groups with potential to influence organizational decisions and actions. These groups can give rise to four essential elements to consider in regard to the organization: coordination, organizational loyalties, sense of identification, and power (Simon, 1982).

From the organizational institutionalization perspective: "When a formal organization develops informal norms and values in addition to the formal variety, it acquires institutional features, and one speaks of institutionalized organizations" (Christensen et al., 2007: 38). An institutionalized organization can be understood as a special type of organization with the following traits: is highly legitimate; has developed a consistent and effective work conduct; is valued by key internal and external actors; has created an effective way of dealing with multiple conflicts and complex and contradictory objectives; meets its objectives, which are usually imposed, without causing collateral damage; is capable of immediate intervention when an unwanted rule begins to take root; is capable of understanding and generating solutions to internal and external problems, and is capable of constantly adapting to changes in the environment (Boin \& Christensen, 2008).

Therefore, organization institutionalization is important inasmuch as governments usually create organizations to meet goals and solve new or persistent social problems, which can constantly change in volatile environments. Organizations must thus develop and execute effective solutions in line with prevailing norms and values in their communities, and at the 
same time, secure or gain support from key internal and external actors in a limited period set by these key actors (Boin \& Christensen, 2008). Such situation can result in an uncertain and, to a certain degree, hostile attitude toward the organization, which can deal with the situation using acquired institutional characteristics that can increase its survival opportunities. Institutionalization is an interruptible and reversible process when the organization and its established norms fail to adapt, execute, and deliver their expected results, which does not necessarily mean their disappearance (Boin \& Christensen, 2008: Christensen, et al, 2007).

\section{STRATEGIC PLANNING}

In the public sector, planning is a process aimed at providing sense and coherence to actions carried out by governmental organisms to meet certain goals determined by the public interest (Sánchez, 2003). SP stands out among different methodologies adopted by public and private organisms (Oropeza, 2004); it shares some of its main characteristics with OT (Bryson, 1988; Pichardo, 2013), but it can also be used as a tool that incorporates CP substantially at different moments during planning development (Arellano, 2004).

This type of planning is not conducted using a single method and can be understood in different ways (Mendoza, 2011); therefore, the following paragraphs present a conceptual framework that, although not intending to provide a unique and generalized application perspective, seek to present some of the fundamental aspects of SP.

SP has three basic characteristics: a) it emanates from the military field; b) it is closely linked with the business sector, and c) in administrative contexts, it involves the construction of medium- and long-term organizational perspectives transcending processes that require immediate attention (Arellano, 2004; PerIman \& Rivera, 2006; Pichardo, 2013). Additionally, SP precedes administration control and allows for the follow-up objectives, priorities, and existing resources to contribute to the fulfillment of the organizational mission (Armijo, 2009).

Due to its multi-scheme nature, which escapes mechanization or its being developed using a unique technique, it is opposed to the assumptions of homogeneity, standardization, prediction, and control, and even though it intends to systematize thought, it is not conceived as a static process, but motivated by constant reflection and human constructions that depend on the comprehension of context dynamics, including both societal values linked with its history and real actors in specific circumstances (Arellano, 2004). Thus, SP is a continuous process focused on creativity, imagination, and the search for innovative alternatives, yet in touch with 
reality (Arellano, 2004). It is a process where possibilities are planned within a specific context, and it seeks to meet crucial or strategic goals (Perlman \& Rivera, 2006).

SP regards strategy as an effort to establish even closer relationships among society, individuals, and organizations in an essentially interrelated world (Arellano, 2004) where the context is built and transformed by society's actors themselves. Accordingly, strategy becomes an essential principle to society because it allows its different groups to elaborate and execute decisions bearing always in mind the expectations of other groups (Arellano, 2004).

Table 1. Components of Strategic Planning

\begin{tabular}{|c|c|c|c|}
\hline Components & Timing for development & \multirow{3}{*}{$\begin{array}{l}\text { General characteristics } \\
\text { Must be clear, concise, } \\
\text { simple, understandable, } \\
\text { and represent a challenge } \\
\text { and an inspiration to } \\
\text { organization members; } \\
\text { involves the key actors } \\
\text { affected by the } \\
\text { organization, their values } \\
\text { and formal and informal } \\
\text { institutions; takes time } \\
\text { and context into account; } \\
\text { is flexible and adaptable } \\
\text { to changes in time; is } \\
\text { realistic; goals are } \\
\text { intended to be achieved } \\
\text { in the medium or long } \\
\text { term; seeks to create } \\
\text { cohesion and a sense of } \\
\text { belonging among the } \\
\text { actors involved with the } \\
\text { organization and } \\
\text { responsible for its goals; is } \\
\text { created with viability in } \\
\text { mind; provides a direction } \\
\text { to the organization. }\end{array}$} & Specific characteristics \\
\hline Strategic mission & \multirow[b]{2}{*}{ Beginning of planning } & & $\begin{array}{l}\text { Foremost organizational } \\
\text { concern; expresses the } \\
\text { main goal; ideal yet } \\
\text { realistic image; requires a } \\
\text { preliminary diagnosis, } \\
\text { even if it is intuitive and } \\
\text { non-systematized. }\end{array}$ \\
\hline Strategic vision & & & $\begin{array}{c}\text { Represents what the } \\
\text { organization expects to } \\
\text { be and the traits it should } \\
\text { display in the future; } \\
\text { involves organizational } \\
\text { actors at the emotional } \\
\text { and state of mind levels. }\end{array}$ \\
\hline Strategic diagnosis & $\begin{array}{l}\text { After creating the } \\
\text { mission and vision } \\
\text { statements and before } \\
\text { implementing the } \\
\text { strategy. }\end{array}$ & $\begin{array}{l}\text { Is flexible and adaptable } \\
\text { to changes in time; must } \\
\text { be realistic; is generated } \\
\text { with viability in mind; } \\
\text { takes into account the key } \\
\text { actors affected by the } \\
\text { organization, their values } \\
\text { and formal and informal } \\
\text { institutions; takes time } \\
\text { and context into account. }\end{array}$ & $\begin{array}{l}\text { A situational analysis tool } \\
\text { to build possible realities } \\
\text { and determine possible } \\
\text { relevant variables; } \\
\text { compares the } \\
\text { organization's intent, the } \\
\text { strategic problem, and } \\
\text { the dynamics in a specific } \\
\text { context; collects and } \\
\text { analyzes information } \\
\text { from actors in the } \\
\text { organization; detects } \\
\text { both issues and }\end{array}$ \\
\hline
\end{tabular}




\begin{tabular}{|c|c|c|c|}
\hline & & & $\begin{array}{l}\text { opportunities; determines } \\
\text { key internal and external } \\
\text { actors; entails analyses of } \\
\text { human and financial } \\
\text { resources and products } \\
\text { and services demand, as } \\
\text { well as a control system; } \\
\text { integrates SWOT, } \\
\text { organizational, and } \\
\text { situational analysis } \\
\text { centered on organization } \\
\text { members morale. }\end{array}$ \\
\hline Strategic objectives & $\begin{array}{l}\text { They are created once } \\
\text { the mission and vision } \\
\text { statements have been } \\
\text { established and a } \\
\text { strategic diagnosis has } \\
\text { been performed. }\end{array}$ & $\begin{array}{l}\text { Are flexible and adaptable } \\
\text { to changes in time; must } \\
\text { be realistic; are generated } \\
\text { with viability in mind; } \\
\text { involve the key actors } \\
\text { affected by the } \\
\text { organization, their values, } \\
\text { and formal and informal } \\
\text { institutions; take time and } \\
\text { context into account. }\end{array}$ & $\begin{array}{l}\text { Represent a forecast of } \\
\text { future results pursued by } \\
\text { the organization within its } \\
\text { action framework; are } \\
\text { directly associated with } \\
\text { the mission; are key } \\
\text { results planned for the } \\
\text { future; are action paths } \\
\text { leading to concrete } \\
\text { outcomes; involve } \\
\text { political, administrative, } \\
\text { and rational decision- } \\
\text { making; do not change } \\
\text { the mission. }\end{array}$ \\
\hline Tactics & $\begin{array}{c}\text { They are established } \\
\text { based on strategic } \\
\text { objectives. }\end{array}$ & $\begin{array}{l}\text { Are clear, concise, and } \\
\text { understandable; are } \\
\text { flexible and adaptable to } \\
\text { changes in time; must be } \\
\text { realistic; are generated } \\
\text { with viability in mind; } \\
\text { involve the key actors } \\
\text { affected by the } \\
\text { organization, their values, } \\
\text { and formal and informal } \\
\text { institutions; take time and } \\
\text { context into account. }\end{array}$ & $\begin{array}{l}\text { Are operative or } \\
\text { functional policies; are } \\
\text { specific actions; they } \\
\text { comprise the way in } \\
\text { which available resources } \\
\text { can be mobilized and } \\
\text { transformed to meet } \\
\text { specific goals stated by } \\
\text { the mission; they may } \\
\text { emerge as a consequence } \\
\text { of an unforeseen } \\
\text { situation, that is, they can } \\
\text { be reactions to diverse } \\
\text { situations; point at } \\
\text { problems to produce an } \\
\text { advantageous situation; } \\
\text { always allow for actions } \\
\text { directed toward the main } \\
\text { established goal; involve } \\
\text { and anticipate the nature } \\
\text { of the actors affected by } \\
\text { the organization; } \\
\text { implement necessary } \\
\text { resources at strategic } \\
\text { times and spaces; }\end{array}$ \\
\hline
\end{tabular}




\begin{tabular}{|c|c|c|c|}
\hline Strategic evaluation & $\begin{array}{l}\text { It is the last stage of SP, } \\
\text { but is present in every } \\
\text { strategic moment. }\end{array}$ & $\begin{array}{l}\text { Must be clear, concise, } \\
\text { simple, understandable, } \\
\text { and represent a challenge } \\
\text { and an inspiration to } \\
\text { organization members; } \\
\text { involves the key actors } \\
\text { affected by the } \\
\text { organization, their values } \\
\text { and formal and informal } \\
\text { institutions; takes time } \\
\text { and context into account; } \\
\text { is flexible and adaptable } \\
\text { to changes in time; is } \\
\text { realistic; helps in creating } \\
\text { cohesion and a sense of } \\
\text { belonging among the } \\
\text { actors involved with the } \\
\text { organization and } \\
\text { responsible for its goals; is } \\
\text { generated with viability in } \\
\text { mind; provides a direction } \\
\text { to the organization. }\end{array}$ & $\begin{array}{l}\text { Consists in a constant } \\
\text { review of the actions } \\
\text { undertaken by the } \\
\text { organization to determine } \\
\text { accomplishment of } \\
\text { established goals and } \\
\text { objectives; is comprised } \\
\text { by the relationship } \\
\text { between means and } \\
\text { ends; requires an } \\
\text { effectiveness analysis that } \\
\text { takes into account } \\
\text { synergy, experience and } \\
\text { learning, self-sufficiency, } \\
\text { risk, and strategic } \\
\text { innovation; evaluates, for } \\
\text { the most part, the impact } \\
\text { of the organization, its } \\
\text { actions, and products. }\end{array}$ \\
\hline
\end{tabular}

Source: Self-elaboration based on Arellano, et al, (2012); Perlman and Rivera (2006); Arellano (2004); Mendoza (2011); Porter (1980); Armijo (2009); Sun-Tzu (1989); Arellano, Cabrero, and Castillo (2000); Surdez (2011); Arce, et al. (2012); and Sánchez (2012).

Consequently, creating a strategy consists in devising different ideas or pathways in pursuit of the main goal, and after that, the pathway leading closest to the established goal is determined-the chosen path must consider the most possibilities and approaches. One of the main conditions for a strategy to work properly is the need to clearly establish such strategy, and also to acknowledge the different organizational actors as essential for success; failing to do so would result in a useless organizational strategy (Arellano, 2004). Table 1 presents a systematic view of the main components of SP in terms of mission, strategic vision, and diagnosis, including contextual analyses of systems, SWOT, objectives, tactics, and strategy evaluation.

Despite the capacity of morale to potentiate the energy and enthusiasm of the organization's members, or oppositely, its potential to cause the disappearance or stagnation of the organization (Sun-Tzu, 1989), morale has been scarcely addressed by SP and OT theories. Morale consists in the mood of an organization's members with respect to the objectives, the mission, or a charismatic individual, group of individuals, ${ }^{4}$ or entity (Ossinovski, 2010). Organizational morale must never be debilitated, it rather needs to be monitored and

\footnotetext{
${ }^{4}$ Such as those described by Webber (1998).
} 
stimulated, since motivation is considered to determine productivity: cooperation is available only from employees who are motivated and willing to collaborate (Arellano, et al., 2000).

\section{CITIZEN PARTICIPATION}

$\mathrm{CP}$ is a collective act based on individuals and their decisions, which are made as a means to participate voluntarily in public affairs of their interest with the aim of achieving certain common goals (Merino, 2010). It can also be thought of as social action aimed at increasing citizen control and influence on the use of public resources by interacting with the government institutions administrating such resources; therefore, its goal is to achieve the common good without assuming any part of the State's responsibility to any extent (Tejera, 2006).

It is an essential characteristic of democratic governments, which seek to reduce the distance between citizens and their representatives (González, 2007), inasmuch as it advances democratic culture, serves as a method to make public administration and decisions more efficient, and legitimizes governments (Ziccardi, 2004). CP is not useful only for citizens, it also contributes to increasing governance margins and consequently to making formal progress in the democratization of local political life (Casas, 2009); in other words, it exerts a positive effect on a society's democratic progress, and it can thus be considered as an indispensable element of an adequate government (Ochman, 2004).

The basic, intertwined elements that allow for its effectiveness are: I) government ruling, in the form of laws, regulations, or other forms; II) sufficient, accessible, and reliable information; III) citizen willingness to participate; IV) real participation possibilities; V) resources; VI) knowledge and capability to achieve participation; VIII) the possibility of citizens to be heard and to have an effective influence on public decisions, and mostly, IX) confidence in the institutions that promote participation (Bañez, 1999; Montesinos, 2004; González, 2007; Casas, 2009).

CP does not end at the ballot; in fact, authors such as Merino (2010) state that it begins with the election of representatives. There are certain CP forms that can be identified as such: activities carried out by citizens in campaigns undertaken by political parties in favor of a chosen candidate; collective or community activities aimed at specific targets; actions resulting from a specific conflict (Merino, 2010); opinions about public affairs and government performance; promotion of pressing issues for inclusion in the public agenda; discussion on laws, programs, 
and budgets; formal or informal citizen cooperation in policy implementation; evaluation of the effect of public policy implementation and scrutiny of public powers; counterproposals of alternative policy, and human rights claims (Ramos \& Reyes, 2005).

It should be noted that CP takes different forms in each country and circumstances. On the other hand, not every act involving citizen activity can be considered $\mathrm{CP}$, but only those taking place under the rule of law; otherwise, the act would not be CP but upward rebellion or downward intervention (Merino, 2010).

Finally, it must be added that governments oftentimes create forms of CP intended only to legitimize previously made government decisions (Ziccardi, 2004), or to establish or perpetuate a corporate apparatus in which, taking advantage of government agencies, programs, subsidies, and other forms of support or services, citizens are led to controlled or subordinated actions, or actions related only to certain expected 'gratuities' emanating from the government, all of which is far from participation in the sense of transferring citizen demands and interests to the government apparatus as a key element of public administration processes (Rossell, 2010).

\section{TAUS}

Territory-based administrative units were short-lived in Ecatepec, second municipality in the country in terms of total population (1,677,678 inhabitants) among 2,457 municipalities, and characterized by its high population density $(10,789$ inhabitants per square kilometer), as it is throughout the northeast of the Valley of Mexico metropolitan area (INEGI, 2015), where Ecatepec is located (see image 1); the municipality presents a very low social backwardness Index ${ }^{5}$ (Coneval, 2015). The electoral roll in the municipality includes 1,113,000 people, which represents $12.2 \%$ of the total State of Mexico population and makes it prone to clientelism. Ecatepec is part of a region in the northeast of the Valley of Mexico metropolitan area where nine of its 76 territorial divisions (Iztapalapa, Gustavo A. Madero, Venustiano Carranza, and Iztacalco in Mexico City, plus Ecatepec, Nezahualcóyotl, Texcoco, Chimalhuacán, and La Paz in the State of Mexico) were the scene of 42.1\% of petty crimes in 2012 (Medina, 2017).

\footnotetext{
${ }^{5}$ In Mexico, this indicator is calculated by the National Council for Social Development Policy Evaluation (Coneval) based on information grouped in five criteria (education, access to health care services, household quality, basic household utilities, and availability of household assets) obtained by censuses and surveys, such as INEGI's inter-censual population survey.
} 
ECATEPEC MUNICIPALITY IN THE METROPOLITAN AREA OF MEXICO VALLEY (MAMV)

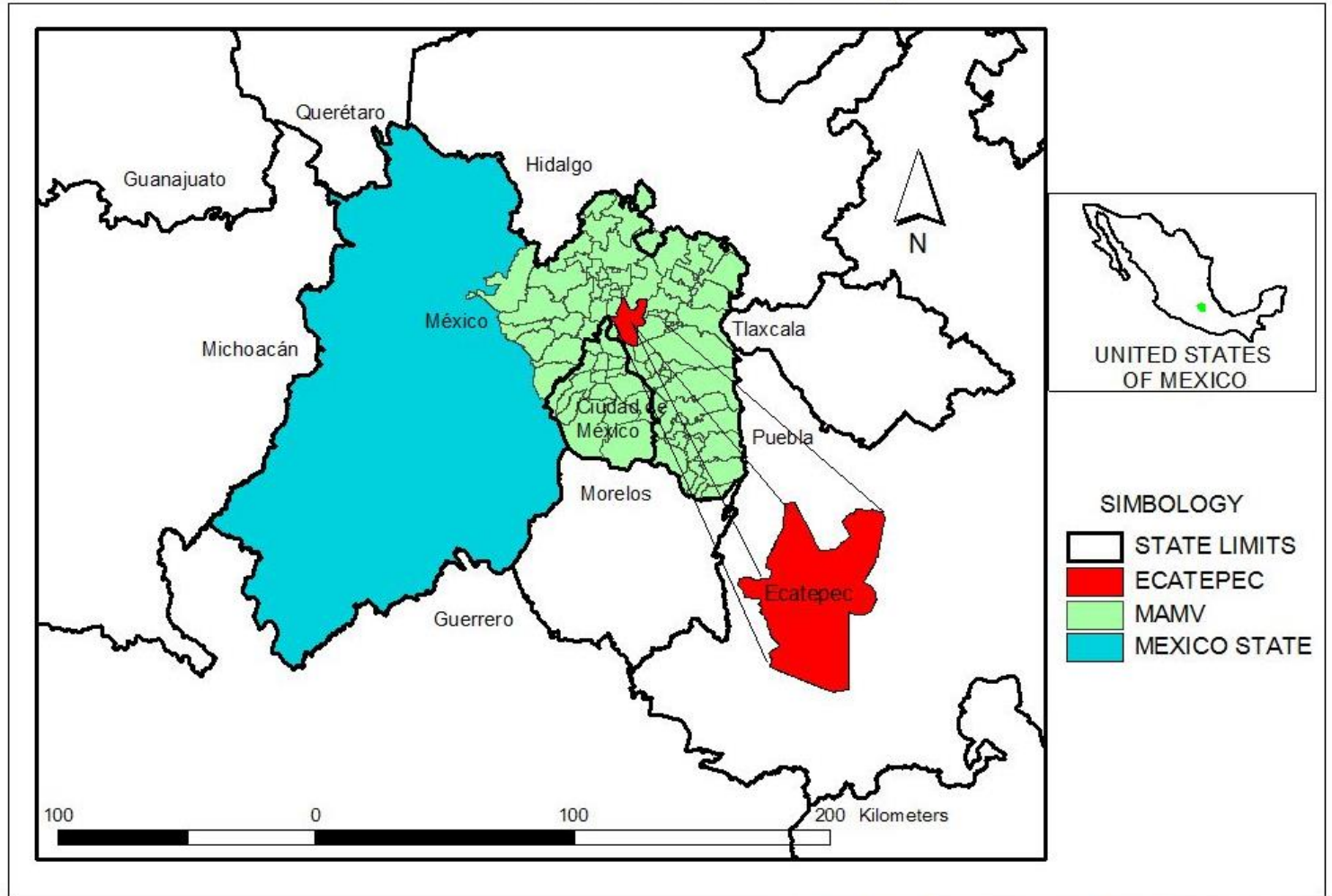

Elaboró: Pablo Armando Cruz Hernández

In this general context, some of the events involved in the creation, operation, and termination of TAUs took place as explained in the following paragraphs. In line with its faculties to secure the adequate functioning of public administration (Gaceta, 2015), the local government indicated the need to pursue a "Progressing Municipality" (Gaceta, 2013b) project in its 2013 Municipal Development Plan (MDP), which proposed the establishment of five territorial units with their own offices. In January, 2013, the newly elected mayor presented a proposal to reform the municipal law before the cabildo, which included the aforementioned TAUs; the proposal obtained a majority of votes and the agencies were created and established in article 70 of the municipal law (Gaceta, 2013a).

According to what the MDP and the municipal law had established, the objectives of the TAUs were to promote administrative closeness and agility in different areas as well as the inclusion of organized CP in actions implemented by the government via close and permanent contact between the TAUs and auxiliary authorities, such as delegations, sub-delegations, and citizen participation councils (Gaceta, 2013b). The 2013 municipal law also stated that the TAUs had the role of increasing the efficiency of municipal public services and every official procedure in the municipality (Gaceta, 2013a). Informally, in 2013, the mayor stated additional TAU 
objectives: narrowing the gap between the government and its citizens, improving the provision of public services, and assisting the municipal administration in meeting its goals (Mileno, 2013; Villa, 2013). The MDP referred to the units as de-concentrated entities as much as decentralized agencies (Gaceta, 2013b), which suggests a lack of clear categorization criteria. ${ }^{6}$ In regard to their tasks, this study conceives TAUs as horizontal specialization organizations, which consists in grouping one or different tasks in one or several units associated with certain positions, but they were also characterized by a certain degree of vertical coordination, as indicated by the presence of a hierarchical element for unit regulation (Christensen et al., 2007).

In 2015, TAUs had been operating for two years and they represented an expansion of the administrative system. The criteria used to distribute the units were Ecatepec's electoral districts (XXI, XXII, XXXIII, and XLII) instead of more adequate criteria such as the size of the population they served, territorial extension, population density, marginalization per locality, or difficulty to access the corresponding office from the different neighborhoods in the area, as can be appreciated in Image 2.

Consequently, the criteria used to determine location and territory failed to help these young organizations to build efficient working procedures while they sought support from key actors in a volatile environment characterized by constant change in priorities, insufficient resources, and objectives designed and assigned by different agencies; additionally, they were given too short a time to achieve their problem resolution capacity and demonstrate their usefulness (Boin \& Christensen, 2008).

Little or no relationship was observed between the units' operation and the goals established by municipal law and the MDP; the TAUs rather acted as:

\footnotetext{
${ }^{6}$ Decentralization consists in the delegation of authority from a central government to intermediate or local governments, to quasi-autonomous government bodies, or to the private sector, which become capable of performing public functions. There are three forms: political, fiscal, and administrative decentralization. Administrative decentralization can be complete when the local government takes full responsibility over personnel and faculties, or controlled (de-concentration) when the organism accepting authority is held accountable by the government transferring authority (Olsen, 2007).
} 
Image 2. TAU's coverage area, location, population density $\&$ accessibility

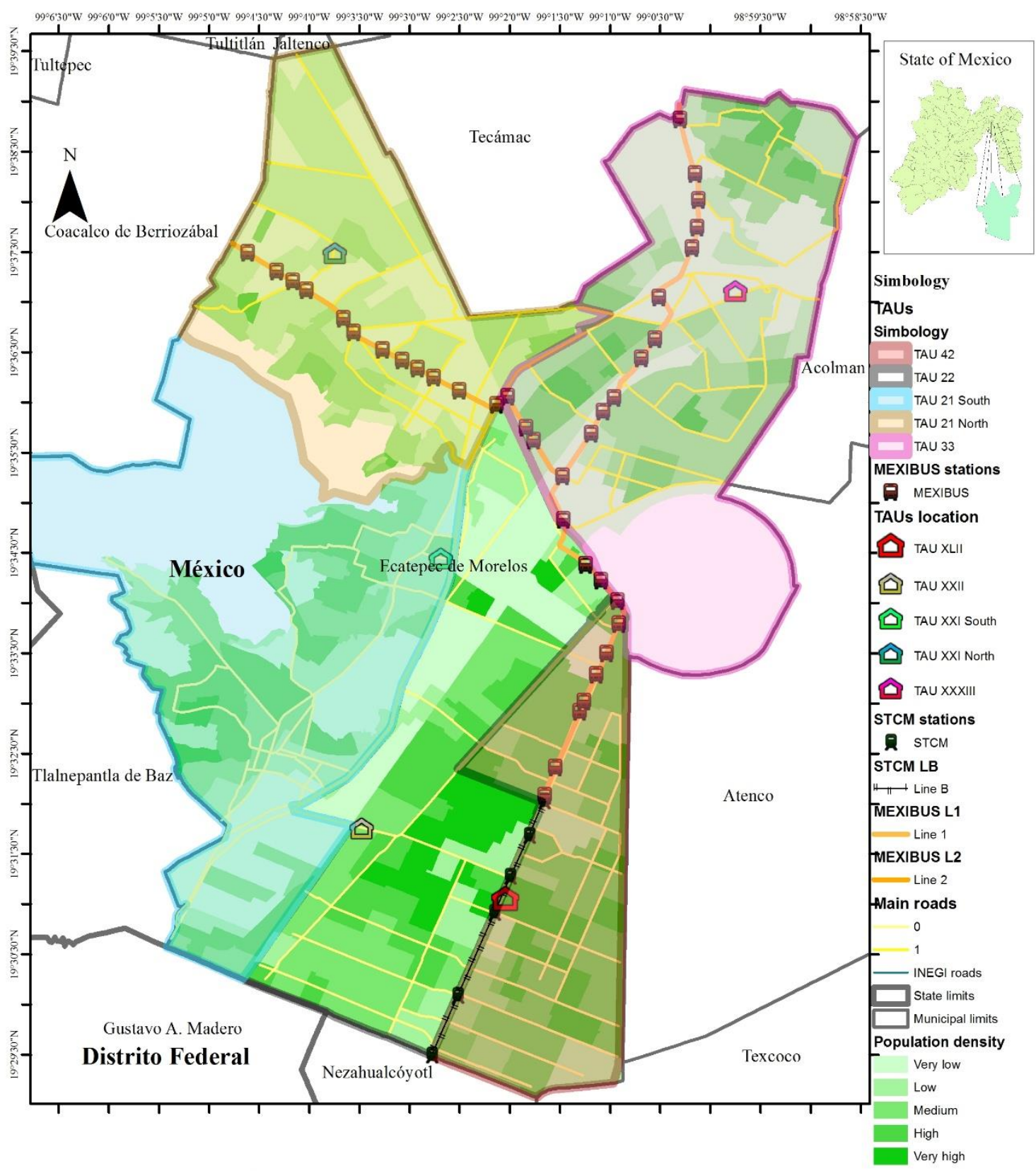

$\begin{array}{llllll}0 & 0.5 & 1 & 2 & 3 & 4\end{array}$

Kilometers Scale: 1 centimeter equals 1 kilometers Made by: Pablo Armando Cruz Hernández 
a. operative centers for public programs, since most of the tasks carried out by the units were in line with the objectives of two municipal programs: "Ecatepec te queremos verde" and "Ecatepec te queremos más limpio" ("Ecatepec, we want you green" and "Ecatepec, we want you cleaner");

b. distribution and promotion centers of federal and state public programs;

c. CP mediators and peace keepers, by negotiating and controlling citizen claims and demands of any kind;

d. CP control agents, by canalizing CP toward electoral projects.

Therefore, ever since their design and throughout their existence, meeting the objectives established by both municipal law and the MDP was unlikely for TAUs, since their design lacked proper planning, lost sight of a subsequent institutionalization, and disregarded the context and its actors, norms, values, and formal and informal practices. To put it another way, they were not designed as organisms aimed at reducing the gap between the government and the citizenry or at helping to make public administration and service provision more efficient. Consequently, their potential institutionalization was unlikely and even their capacity to survive political/administrative changes was scarce.

As recently created organizations, TAUs could have enjoyed an initial honeymoon period in which they built effective work forms to avoid their failure (Boin \& Christensen, 2008), but they were never truly in charge of any kind of service and operated according to the mayor's political needs. During their existence, nearly three thousand people per day approached the city hall to request support in the form of tasks that had supposedly been assigned to the TAUs (NEM, 2015). Therefore, they were not able to develop the institutionalized organization traits described by theory that were presented earlier in this article.

In the end, the 2016 administration decided to close the TAUs. Nevertheless, the actors in charge of their termination-town council and municipal presidency-declared that they were not aware of the reasons behind the decision to terminate the agencies in questionnaires, personal interviews, and journals. They could not tell whether there was some type of evaluation or it had been due to other factors, except for a vague idea around redundant government functions. Given that the TAUs were not included in the new government project, they voted for eliminating the units. 


\section{THEORETICAL ASPECTS IDENTIFIED IN THE CASE OF TAUS}

A theoretical perspective can respond to the following question: What were the main theoretical factors involved in the decision to remove the TAUs? The response is given in Table 2, which identifies the theoretical elements that can help to explain why it was impossible for TAUs to become institutionalized, as well as their termination.

The information in the table shows that a wide array of relevant theoretical aspects were disregarded and left out during the design, creation, operation, and termination of TAUs, since their creation and termination responded to political reasons that were not concerned with the creation of a government organization capable of delivering the competence ordered by law for the municipal government. Similarly, the new government conducted the termination as an administrative procedure instead of a decision with a potential impact on government performance.

This explains why the TAUs were used by the mayor's power networks as propaganda instruments to advance personal political agendas; it also explains why those units were unable to develop necessary traits for their institutionalization.

Table 2. Theoretical aspects associated with public organization termination

\begin{tabular}{|c|c|c|}
\hline Author & Theoretical aspects & $\begin{array}{c}\text { Theoretical aspects observed in } \\
\text { the case of TAUs }\end{array}$ \\
\hline \multicolumn{3}{|c|}{ Organizational theory } \\
\hline $\begin{array}{l}\text { Max Weber } \\
\text { (1998) }\end{array}$ & $\begin{array}{l}\text { There is a special relationship between appointed } \\
\text { and elected officials }\end{array}$ & $\begin{array}{l}\text {-Constant intervention of } \\
\text { elective bureaucracy in } \\
\text { organizations. } \\
\text {-Interruption of the units' form } \\
\text { of operation. } \\
\text {-Creation of effective practices } \\
\text { interrupted. } \\
\text {-Goals different from those } \\
\text { legally declared were included. } \\
\text {-Elective bureaucracy approved } \\
\text { arbitrary creation of organisms. } \\
\text {-Elective bureaucracy was } \\
\text { uninterested or ignored the } \\
\text { work of approved agencies. }\end{array}$ \\
\hline
\end{tabular}




\begin{tabular}{|c|c|c|}
\hline Simon (1982) & $\begin{array}{l}\text {-Three types of organizational actors: high- } \\
\text { ranking actors, employees, and beneficiaries. } \\
\text {-Organizational actors seek economic, security, } \\
\text { and prestige ends. } \\
\text {-Organizations are not purely rational. } \\
\text {-Organizations should be created using an } \\
\text { inclusive approach that corresponds to the value } \\
\text { system in the community to a greater extent than } \\
\text { what is legally established. } \\
\text {-Organizational actors can interfere with the } \\
\text { organization to achieve personal goals. } \\
\text {-Loyalties to members, groups, or departments is } \\
\text { generated. } \\
\text {-Power can emanate from any part of the } \\
\text { organization and depends on the power to } \\
\text { penalize or encourage individuals. } \\
\text {-A powerful actor has the possibility to create } \\
\text { groups within the organization to support their } \\
\text { personal, non-organizational goals. }\end{array}$ & $\begin{array}{c}\text {-Agency design disregarded } \\
\text { strategic factors such as context, } \\
\text { values, and territory. } \\
\text {-Key actors were omitted during } \\
\text { design, operation, and } \\
\text { termination. } \\
\text {-Pursuit and execution of } \\
\text { objectives different from those } \\
\text { formally established. } \\
\text {-Formal actors in the } \\
\text { organization working toward the } \\
\text { satisfaction of elective } \\
\text { bureaucracy goals to secure } \\
\text { their permanence in the } \\
\text { organization. } \\
\text {-Creation, operation, and } \\
\text { termination led by habit. } \\
\text {-Organization loyal to the mayor } \\
\text { and their political party. } \\
\text {-Absence of evaluation } \\
\text { processes during operation and } \\
\text { termination. } \\
\text {-Organization's legitimation and } \\
\text { institutionalization were } \\
\text { obstructed. } \\
\text {-Impossibility to adapt to and } \\
\text { survive specific contexts and } \\
\text { changes therein. } \\
\text { achieve personal objectives. } \\
\text {-Operating staff seeks to comply } \\
\text { with tasks assigned by the mayor } \\
\text { as a way to avoid penalties. }\end{array}$ \\
\hline $\begin{array}{c}\text { Arellano, } \\
\text { Cabrero, and } \\
\text { Castillo (2000) }\end{array}$ & $\begin{array}{c}\text {-Organizations in the public sector can be created } \\
\text { only in response to a law or regulation. }\end{array}$ & $\begin{array}{c}\text {-Arbitrary creation, operation, } \\
\text { and termination of units as a } \\
\text { response to mandates in valid } \\
\text { municipal law and development } \\
\text { plan }\end{array}$ \\
\hline $\begin{array}{c}\text { Boin and } \\
\text { Christensen } \\
(2008)\end{array}$ & $\begin{array}{l}\text {-Goals created in a complex and volatile context } \\
\text { composed of impatient politicians, judgmental } \\
\text { communications media, and scarce resources". } \\
\text {-Institutionalized organizations are highly } \\
\text { legitimate, have consistent and effective work } \\
\text { practices, are valued by key players, can try and } \\
\text { achieve various types of objectives, act upon the } \\
\text { consolidation of unwanted norms, understand } \\
\text { and solve internal and external problems, and } \\
\text { manages to adapt to changes in the context. } \\
\text {-An organization must develop and provide } \\
\text { effective solutions matching the prevailing norms } \\
\text { in its community. } \\
\text {-Organizations have a short time to achieve } \\
\text { objectives designed by and turned over to } \\
\text { separate government bodies, as well as to }\end{array}$ & $\begin{array}{l}\text {-Ambiguous objectives were } \\
\text { created. } \\
\text {-Impossibility to fully comply } \\
\text { with legally established } \\
\text { objectives and functions. } \\
\text {-Lack of citizenry awareness of } \\
\text { its existence and lack of } \\
\text { legitimacy thereof. } \\
\text {-Short time to produce work } \\
\text { procedures with enough } \\
\text { acceptance by key actors and } \\
\text { citizenry. } \\
\text {-Incapacity to adapt to changes } \\
\text { in the context. } \\
\text {-Lack of congruence between } \\
\text { organizational values and goals; }\end{array}$ \\
\hline
\end{tabular}




\begin{tabular}{|c|c|c|}
\hline & $\begin{array}{l}\text { demonstrate their capacity to solve problems and } \\
\text { provide value to key political and social actors. } \\
\text {-Failure focuses attention on the organization. }\end{array}$ & $\begin{array}{l}\text { in practice, values are aligned to } \\
\text { political actors' interests rather } \\
\text { than community service. } \\
\text {-Attention was frequently being } \\
\text { deflected from established } \\
\text { objectives, established the } \\
\text { constant attention of agents } \\
\text { that rate the organization. } \\
\text {-Inability to fully resolve external } \\
\text { problems } \\
\text {-Failure focuses attention of } \\
\text { different actors on TAUs. }\end{array}$ \\
\hline $\begin{array}{l}\text { Christensen, } \\
\text { Laegreid, Roness, } \\
\text { and Rovik (2007) }\end{array}$ & $\begin{array}{l}\text {-Both formal and informal institutions affect } \\
\text { organizational decision-making process. }\end{array}$ & $\begin{array}{l}\text {-Constant intervention in } \\
\text { organizational operation and in } \\
\text { establishing ways to meet goals. } \\
\text {-The organization was used to } \\
\text { achieve goals that differed from } \\
\text { those established for the } \\
\text { organization. }\end{array}$ \\
\hline $\begin{array}{l}\text { Rainey and Jung } \\
\qquad(2015)\end{array}$ & $\begin{array}{l}\text {-It is important for public organizations to identify } \\
\text { their type of objectives and how ambiguous or } \\
\text { clear those objectives are. } \\
\text {-Objective creation can be under pressure from } \\
\text { different actors to create ambiguous objectives } \\
\text { and to act in accordance with goals that differ } \\
\text { from the organization's own goals. }\end{array}$ & $\begin{array}{l}\text {-Establishment of fixed and } \\
\text { widely ambiguous goals. } \\
\text {-General yet blurred idea about } \\
\text { the goals sought by the } \\
\text { organization. } \\
\text {-Organization was used by } \\
\text { elective bureaucracy in the } \\
\text { pursuit of personal goals. }\end{array}$ \\
\hline \multicolumn{3}{|c|}{ Strategic planning } \\
\hline Arellano (2004) & $\begin{array}{l}\text {-SP is a continuous process focused on creativity, } \\
\text { imagination, and the search for innovative } \\
\text { alternatives, yet without departing from reality. } \\
\text {-Strategy is an effort toward ever closer } \\
\text { relationships among society, individuals, and } \\
\text { organizations in an essentially interrelated world. } \\
\text {-Strategy is an essential principle; it allows } \\
\text { different society groups to make and execute } \\
\text { decisions. } \\
\text {-Strategy needs to be clearly established, and the } \\
\text { different organizational actors responsible for its } \\
\text { success must be recognized. }\end{array}$ & $\begin{array}{l}\text {-Scarce comprehensive and } \\
\text { continuous planning. } \\
\text {-Commitments were established } \\
\text { based on needed services, but } \\
\text { the organization was incapable } \\
\text { of honoring such commitments. } \\
\text {-Distance between citizenry and } \\
\text { organizations increased. } \\
\text {-Habit and everyday experience } \\
\text { determined operation and } \\
\text { means to meet goals. } \\
\text {-Key organizational actors left } \\
\text { out of organizational processes. }\end{array}$ \\
\hline $\begin{array}{l}\text { Different authors } \\
\text { presented in } \\
\text { Table } 1 \text { (strategic } \\
\text { planning) }\end{array}$ & $\begin{array}{l}\text { Elaboration of strategic mission, vision, diagnosis, } \\
\text { objectives, tactics, and evaluation. }\end{array}$ & $\begin{array}{l}\text {-Absence of clear, concise, and } \\
\text { short (yet not comprehensive) } \\
\text { mission and vision statements } \\
\text { that can be easily understood by } \\
\text { organizational actors. } \\
\text {-Fixed objectives opposed } \\
\text { adaptation to changes in the } \\
\text { context. } \\
\text {-Territorial characteristics were } \\
\text { disregarded. } \\
\text {-No comprehensive diagnosis } \\
\text { and evaluation processes }\end{array}$ \\
\hline
\end{tabular}




\begin{tabular}{|c|c|c|}
\hline & & $\begin{array}{c}\text { identified during the creation, } \\
\text { operation, or termination of the } \\
\text { organization } \\
\text {-Low accessibility to units; } \\
\text { therefore, diverse actors were } \\
\text { automatically excluded. } \\
\text {-Lack of knowledge among } \\
\text { citizenry about the existence of } \\
\text { the organizations, which } \\
\text { resulted in low sense of } \\
\text { belonging toward organizations. } \\
\text {-Available resources to meet } \\
\text { goals, but used in pursuit of } \\
\text { personal political goals and not } \\
\text { in accordance with the needs of } \\
\text { the moment and the strategic } \\
\text { spaces. }\end{array}$ \\
\hline \multicolumn{3}{|c|}{ Citizen participation } \\
\hline Merino (2010) & $\begin{array}{c}\mathrm{CP} \text { is a collective act based on individuals and } \\
\text { their decisions, which are made as a means to } \\
\text { participate voluntarily in public affairs of their } \\
\text { interest. }\end{array}$ & $\begin{array}{l}\text {-Organizations employed to } \\
\text { control participation in public } \\
\text { affairs. } \\
\text {-Citizenry was left out and was } \\
\text { incapable of fully participating in } \\
\text { the design, operation, and } \\
\text { decision to terminate the units. }\end{array}$ \\
\hline González (2007) & $\begin{array}{l}\text { A fundamental element in democratic } \\
\text { governments which seeks to reduce the gap } \\
\text { between citizens and their representatives. }\end{array}$ & $\begin{array}{l}\text {-Organizations sought to control } \\
\text { CP instead of integrating it to } \\
\text { administration. } \\
\text {-In practice, the distance } \\
\text { between the citizenry and the } \\
\text { government increased. }\end{array}$ \\
\hline Ziccardi (2004) & $\begin{array}{c}\text {-Advances democratic culture and serves as a } \\
\text { method to increase the efficiency of public } \\
\text { management and decision-making and to support } \\
\text { government legitimacy. } \\
\text {-Forms of CP are usually created only to legitimize } \\
\text { previously made government decisions. }\end{array}$ & $\begin{array}{c}\text {-The organization generated low } \\
\text { legitimacy around itself, which } \\
\text { obstructed its institutionalization } \\
\text { process. } \\
\text {-Government decisions about } \\
\text { organizational creation and } \\
\text { operation were presented to the } \\
\text { citizenry, but CP was not } \\
\text { indicated. }\end{array}$ \\
\hline $\begin{array}{c}\text { Bañez (1999); } \\
\text { Montesinos } \\
\text { (2004); González } \\
\text { (2007); and } \\
\text { Casas (2009) }\end{array}$ & $\begin{array}{l}\text { Basic elements of CP: government rulings; } \\
\text { sufficient, accessible, and reliable information; } \\
\text { willingness to participate and real possibilities, } \\
\text { resources, knowledge, and capacities to do so; } \\
\text { social cohesion; possibility to exert effective } \\
\text { influence on public decisions; confidence in } \\
\text { agencies promoting CP. }\end{array}$ & $\begin{array}{l}\text {-Existing government rulings, but } \\
\text { lack of a real possibility to } \\
\text { readily access sufficient and } \\
\text { reliable information, resources; } \\
\text { low chances to exert an effective } \\
\text { influence on public affairs. } \\
\text {-Information provided to citizens } \\
\text { about the decisions of creating } \\
\text { and terminating the units and } \\
\text { about their operation was scarce } \\
\text { and vague. }\end{array}$ \\
\hline
\end{tabular}




\begin{tabular}{|c|c|c|}
\hline Rossell (2010) & $\begin{array}{l}\text { CP can be used to establish or perpetuate a } \\
\text { corporate apparatus that takes ill advantage of } \\
\text { government agencies, programs, subsidies, and } \\
\text { other forms of support or services; citizens are } \\
\text { led to controlled or subordinated actions, or to } \\
\text { actions taken only in expectance of certain } \\
\text { 'gratuities', all of which differs from participation } \\
\text { as a transference of citizen demands and } \\
\text { interests to the government apparatus as a key } \\
\text { element of public administration processes. }\end{array}$ & $\begin{array}{c}\text {-Limited CP, manipulated by } \\
\text { political interests away from } \\
\text { public administration } \\
\text { improvement. } \\
\text {-Use of granted powers to } \\
\text { control and manipulate CP. }\end{array}$ \\
\hline
\end{tabular}
Source: Self-elaboration.

\section{CONCLUSIONS}

The present study identified that: a) many organizations are created, operated, and terminated in an arbitrary and habit-based fashion, in alignment with special interests of the elective bureaucracy or only to meet legally established requirements or commitments; b) elective bureaucracy has an adverse influence on public organizations and their institutionalization process when it intervenes and directs efforts toward the achievement of personal goals instead of organizational and common good goals; c) institutionalization processes are interrupted when the organization is constantly changing the direction of goals that differ from their natural goals, established when it was created; d) the public sector usually overlooks strategic factors that would contribute to its own benefit when designing, creating, operating, evaluating, and terminating its agencies; e) organizational loyalty and work security agendas result in the organization and its staff working to satisfy the will of the elective bureaucracy or groups in power instead of working toward established goals and the improvement of methods to achieve their goals; f) public agencies often disregard the citizenry and key actors involved in organizational processes; g) ambiguity and the absence of key actors during the creation of organizational objectives and processes opens the door to deviation from established goals; h) rigid and immovable formal goals result in an impossibility to adapt to changes in the context; i) organizational resources are employed in the interest of elective bureaucracy instead of being strategically used in the places and at the time when they must be implemented; j) the citizenry and its participation is excluded from the public sector and its organizations and is regarded as people expecting gratuities to validate previously made decisions; k) OT principles, complemented by SP and CP theories, are useful in the design, creation, operation, and evaluation of public organizations: they make it possible to identify both conflictive and beneficial organizational aspects. 
Based on the theoretical elements used in the analysis presented in this document, we identified and categorized two main themes that the public sector should take into account when designing, creating, operating, and evaluating its agencies if they are to increase the chances of these organizations to acquire organizational traits. The first is organizational actor analysis; the second refers to the analysis of planning and feedback processes. In regard to the first theme, it is convenient to bear in mind that different, specific, and varied actors will be found in each case and environment, and those diverse actors will exert different types of influence on organizational operation. However, enlisting and analyzing the internal and external actors that should be included in the organization's creation and all of the organizational procedures is necessary.

It is also essential to analyze and understand organizational rules and formal and informal values in their specific contexts and in association with their involved internal and external actors as a measure to adapt to the environment and to minimize the possibility of using the organism and its resources to service personal agendas. Understanding such mechanisms will support the creation of a cordial atmosphere where actors are encouraged to internalize and protect organizational objectives, it will also help to avoid the creation of undesirable norms even before they take root, and finally, to develop a forecast of the actors' behavior. Concerning internal actors, it is important for the organization to determine the types of skills it will need to support its tasks in order to recruit qualified staff for the different positions

On the other hand, it is important to understand how elective bureaucracy will intervene and affect the criteria to design, operate, and evaluate a public organization; the creation of effective practices; the setting of objectives and the means to meet them, and also how such intervention will affect staff relationships, with the goal of avoiding or preventing reactions to possible deviations and being able to deal with them, and therefore, anticipate possible environment changes, but also as a way to establish attainable, clear, and as unambiguous as possible objectives to help reduce the possibility of failure and to increase the organization's possibility of developing institutional characteristics.

Additionally, the capacity to perform analyses and make decisions based on reason instead of habit, or according to legally established ordinances, must be called upon to support adequate agency operation and to anticipate contextual changes and possible institutionalization. This also involves the analysis of existing and emerging organizational 
loyalties as a way to prevent unwanted behaviors that may orient organizational efforts toward the accomplishment of special, personal objectives, instead of legitimate ones.

Finally, in connection with planning and feedback, it is important to state a mission or objectives, a vision, a diagnosis, tactics, and feedback and analysis procedures in order to increase the organization's possibilities to acquire organizational traits; those statements must be clear, concise, simple, understandable, flexible, adaptable, realistic, and should represent a challenge to organization members, create cohesion and a sense of belonging, be established using an inclusive and open process, consider timeframes and context, and provide the organization with a direction.

Nevertheless, these recommendations are not intended to be a sort of manual, but only a proposal to be considered by the public sector when it undertakes the creation of agencies bearing in mind their probability to become institutionalized bodies.

\section{LIST OF REFERENCES}

ARCE, et al. The methodology for Strategic Plan Implementation. Journal of applied Research and Technology. 248-261, Abril de 2012.

ARELLANO, et al. Sistemas de Evaluación del Desempeño para organizaciones públicas ¿Cómo construirlos efectivamente? México: CIDE, 2012.

ARELLANO, Gault. Gestión estratégica para el sector público. Del pensamiento estratégico al cambio organizacional. México: Fondo de Cultura Económica, 2004.

ARELLANO, Gault, CABRERO, Enrique y CASTILLO, Arturo. Reformando al gobierno una visión organizacional del cambio gubernamental. México: CIDE, 2000.

ARMIJO, Marlanela. Manual de Planificación Estratégica e Indicadores de Desempeño en el Sector Público. ILPES/CEPAL: Área de Políticas Presupuestarias y Gestión Pública, 2009.

BAÑEZ, Tomasa. Participación ciudadana, sociedad civil y juventud. Universidad de Zaragoza: Acciones e Investigaciones Sociales, 1999.

BOIN, Arjen y CHRISTENSEN, Tom. The Development of Public Institutions. Reconsidering the Role of Leadership" Administration \& Society. Norway: University of Oslo. 271-297, febrero de 2008.

BRYSON, John. A Strategic Planning Process for Public and Non-profit Organizations. Pergamon Journals Ltd. Inglaterra: Long Range Planning, 73-81, 1988.

CASAS, Ernesto. Representación política y participación ciudadana en las democracias. Revista Mexicana de Ciencias Políticas y Sociales. 59-76 Enero/Diciembre. 2009. 
CONSEJO NACIONAL DE EVALUACIÓN DE LA POLÍTICA DE DESARROLLO SOCIAL (Coneval). Índice de Rezago Social 2015. Presentación de Resultados, 2015.

CHRISTENSEN, Tom; LAEGREID, Per; RONESS, Paul; and RøVIK, Arne. Organization Theory and the Public Sector. Instrument, culture and myth. United Kingdom and United States: Routledge, 2007.

CROZIER, Michael y FRIEDBERG, Erhard. El actor y el sistema. Las restricciones de la acción colectiva. México: Alianza Editorial Mexicana, 1990.

FLYVBJERG Bent (2006). Five Misunderstandings About Case-Study Research. Qualitative Inquiry. 219-245 April, 2006. http://journals.sagepub.com/doi/pdf/10.1177/1077800405284363.

BANDO MUNICIPAL. México: H. Ayuntamiento Constitucional de Ecatepec de Morelos 20132015. Gaceta Municipal, $2013 a$.

GACETA MUNICIPAL. Plan de Desarrollo Municipal 2013-2015 del Municipio de Ecatepec de Morelos, Estado de México. México: H. Ayuntamiento Constitucional de Ecatepec de Morelos 2013-2015, 2013b.

BANDO MUNICIPAL. México: H. Ayuntamiento Constitucional de Ecatepec de Morelos 20132015. México: Gaceta Municipal de Ecatepec, 2015.

GONZÁLEZ, Salcedo. La participación ciudadana en el ámbito local, esfuerzo por regenerar la democracia. Revista Sociológica de Pensamiento crítico. 179-186, 2007.

INEGI. Encuesta Intercensal. México: INEGI, 2015.

MEDINA, Mariana. La policía de proximidad en Nezahualcóyotl, estado de México. Tesis para obtener el Grado de Maestría en Economía y Gestión Municipal. Instituto Politécnico Nacional. México: IPN, 2017.

MENDOZA, María. Decisiones estratégicas. Macroadministración. Colombia: Ediciones de la U, 2011.

MERINO, Mauricio. La participación ciudadana en la democracia. México: Instituto Federal Electoral, 2010.

MILENIO. "Alcalde de Ecatepec toma protesta a delegados y subdelegados" MILENIO NOTICIAS. April 06, 2013. Extracted from: http://www.milenio.com/tendencias/Alcalde-Ecatepec-protestadelegados-subdelegados_0_57594245.html

MONTESINOS, Rafael. La participación ciudadana en la modernidad democrática mexicana. 93104, 2004. 
NEM (21 de julio de 2015). "Refuerzan servicios públicos de Ecatepec en temporada vacacional" Noticias de Ecatepec de Morelos. Extracted from: http://www.ecatepec.gob.mx/boletines/ show.php?boletin=2047.

NORTH, Douglass. Instituciones, cambio institucional y desempeño económico. México: Fondo de Cultura Económica, 1995.

OCHMAN, Marta. Sociedad civil y participación ciudadana. Revista Venezolana de Gerencia. 473489, julio/septiembre 2004.

OLSEN Hans Bjørn . Decentralisation and local governance. Module 1: definitions and concepts. 2007.

https://www.eda.admin.ch/content/dam/deza/en/documents/publikationen/Diverses/167288decentralisation-local-governance_EN.pdf

OROPEZA, Alejandro. La evaluación de la función pública en México. México: INAP, 2004.

OSSINOVSKI, Jevgeni. Legitimacy of Political Power in Putin's Russia. Inglaterra: School of Economics and Political Science, 2010.

PARKASH, Aseem. y Potoski, Matthew. (2016). Dysfunctional institutions? Toward a New Agenda in Governance Studies. Regulation \& Governance. Seattle: University of Washington. 115-125, 2016.

PERLMAN, Bruce y RIVERA, Mario. Planeación e Integración Estratégica: Extensión Conceptual y Teórica de un Modelo Aplicado. Revista Chilena de Administración Pública. Estado, Gobierno, Gestión Pública. 112-124, 2006.

PICHARDO, Arlette. Advances in Strategic Planning of the Public Sector in Latin America and the Caribbean: Balance and Perspectives. Quality Issues and Insights in the 21st Century. Centro Internacional de Política Económica, 60-78, 2013.

PORTER, Michael. Competitive Strategy, Techniques for Analyzing Industries and Competitors. Estados Unidos: The Free Press, 1980.

RAINEY, Hall. and JUNG, Chan. A conceptual Framework for Analysis of Goal Ambiguity in Public Organizatios. Journal of Public Administration Research and Theory. Oxford University Press. 7199, January, 2015.

RAMOS, María y REYES, Marcela. Gobiernos locales y participación ciudadana: Hacía un enfoque de gestión estratégica asociada. Espiral. México. 39-66, February/May 2005.

ROSSELL, María. Tercer sector y prestación de servicios sociales públicos: la 'caja negra' de la participación ciudadana en la gestión pública y su impácto en los regímenes de bienestar corporativos. CLAD, Reforma y Democracia. 1-27, June, 2010.

SÁNCHEZ, Alvabera. Planificación estratégica y gestión pública por objetivos. Chile: Instituto Latinoamericano y del Caribe de Planificación Económica y Social - ILPES, 2003. 
SÁNCHEZ, Ernesto. Sobre la necesidad de una visión estratégica en la gestión de programas contra la pobreza. Centro de Estudios Internacionales. El Colegio de México. 484-521, 2012.

SIMON, Herbert. El comportamiento administrativo. Estudio de los procesos decisorios en la organización administrativa. Argentina: Economía de la Empresa, 1982.

SUN-TZU. El arte de la guerra. Segunda edición. Madrid: Fundamentos, 1989.

SURDEZ, Perez y AGUILAR, Morales. (2011). Gestión estratégica en el sector público y en el sector privado: diferencias y similitudes. Ensayo Administración. México: Hitos de Ciencias Económico Administrativas. 39-46, Enero/Abril 2011.

TEJERA, Héctor. Cultura ciudadana, gobiernos locales y partidos políticos en México. Sociológica. Departamento de Sociología. 41-70, 2006.

VILLA, Jorge. (22 de junio de 2013). Firman Acuerdo de Participación y Trabajo Político en compun Movimiento Ciudadano y Movimiento Progresista de Ecatepec. Red-acción. Periodismo a Contraluz. 22 de junio de 2013. Extracted from: http://www.red-accion.mx/2015/12/firmanacuerdo-de-participacion-y.html

WEBER, Max. Economía y Sociedad. Esbozo de sociología comprensiva. Decimoséptima edición, México: Fondo de Cultura Económica, 1998.

ZICCARDI, Alicia. Espacios e instrumentos de participación ciudadana para las políticas sociales del ámbito local. Participación ciudadana y políticas sociales del ámbito local. México: UNAM. 2004.

Trabalho enviado em 13 de fevereiro de 2018.

Aceito em 23 de fevereiro de 2018. 